\title{
PERLINDUNGAN TERHADAP KONSUMEN PADA CACAT PRODUK DFSK 580 TURBO CVT MILIK PT. SOKONINDO AUTOMOBILE BERDASARKAN ASAS KEAMANAN DAN KESELAMATAN KONSUMEN
}

\author{
Arief Tharifi \\ Mahasiswa Magister Ilmu Hukum \\ Email: arieftharifi97@gmail.com
}

\begin{abstract}
Abstrak. Indonesia sebagai Negara strategis dalam investasi telah mengundang sangat banyak investor untuk berbisnis di Indonesia, hal ini salah satunya telah mengembangkan industri otomotif di Indonesia, china sebagai salah satu Negara besar investor dalam bidang otomotif telah berkontribusi dengan dua merk besar yaitu Wuling dan DFSK yang dikelola dibawah PT.SGMW Motors Indonesia dan PT Sokonindo Automobile, beberapa bulan yang lalu muncul tuntutan ganti kerugian terhadap cacat produk yang dipasarkan oleh DFSK, hal ini memicu protes banyak konsumen yang merasa dirugikan, untuk itu penelitian ini menganalisa tentang kasus yang terjadi pada cacat produk DFSK secara hukum, apakah pabrikan China dan aturan hukum mengenai penjaminan produk otomotif di Indonesia telah menjamin perlindungan berdasarkan asas keamanan dan keselamatan konsumen, pada hasil penelitian ini ditemukan bahwa telah tersedianya seperangkat aturan yang memadai dalam pengawasan mutu produk otomotif di Indonesia, tetapi terdapat tindakan pengistimewaan dari pihak pemerintah terhadap produk produk otomotif China.
\end{abstract}

\section{PENDAHULUAN Latar Belakang}

Indonesia sebagai Negara yang terletak di posisi strategis dalam garis lalu lintas perdagangan yang menjadikannya sebagai mitra investasi yang cukup diminati oleh pengusaha-pengusaha Negara lain yang ingin berinvestasi, tidak hanya itu Indonesia memiliki daya tarik investasi yang paling mengutungkan dan menarik investor adalah dengan jumlah penduduk Indonesia yang sangat banyak, dalam proses bisnis dan ekonomi jumlah masyarakat yang banyak sama dengan pasar peminat yang besar pagi pemasaran suatu produk, sehingga hal ini menjadi akan menjadi kemudahan dan keuntungan bagi para investor.

Dalam hal kerjasama ekonomi memang Indonesia sebagai Negara berkembang di asia tenggara tentunya juga sudah banyak menjalin kerjasama ekonomi dengan Negara lain agar mencapai pertumbuhan ekonomi yang diinginkan, sekarang ini Indonesia mendapatkan Investasi terbesar dari dua Negara Asia yaitu Singapura sebagai posisi teratas lalu disusul oleh China.

Indonesia yang memiliki visi sebagai Indonesia Maju tahun 2045, hal ini merupakan sebuah cita cita yang besar mengingat sangat banyak PR yang harus dikerjakan pemerintah agar mencapai target tersebut, Indonesia yang memiliki pertumbuhan ekonomi terdapat pada angka $5 \%$ harus mencapai pertumbuhan sebesar $6 \%-7 \%$, menurut Kementerian Koordinator Perekonomian untuk mencapai target tersebut maka Indonesia membutuhkan kurang lebih Rp.4.800 triliun Investasi dalam setahun. China telah menggelontorkan dananya ke Indonesia sebesar US\$ 13,8 miliar dalam lima tahun terakhir. Total uang yang telah dimasukan oleh China ke Indonesia pada tahun 2019 telah mencapai 4,7 Miliar yang terdiri dari 2000 proyek yang digarap.

Kementrian perindustrian yang dipimpin oleh Airlangga hartanto pernah mengatakan pada tahun 2018 bahwa lima tahun kedepan Indonesia akan mendapatkan Investasi dibidang Otomotif sebesar Rp 100 Triliun sebagai pengembangan Industri Otomotif di Indonesia, Investasi ini digadang-gadang efek dari fokus pengembangan pemerintah Indonesia untuk mempercepat penggunaan kendaraan listrik sebagai kendaraan ramah lingkungan di Indonesia yang telah dituangkan dalam Peraturan Presiden 
Nomor 55 Tahun 2019 tentang Percepatan Program Kendaraan Bermotor Listrik Berbasis Baterai (Battery Electric Vehicle) untuk Transportasi Jalan. Menurut Kemenperin terdapat beberapa industry otomotif besar dunia yang tertarik untuk berinvestasi di Indonesia dengan adanya program pengembangan tersebut yang dilakukan pemerintah. Diantaranya ada pabrikan Jepang seperti Toyota dan Honda , pabrikan Korea Selatan Hyundai dan tentu saja pabrikan China yaitu produsen mobil BYD Automobile Co. Ltd yang merupakan produsen mobil listrik, dan produsen kendaraan komersial, Jianghuai Automobile Co. Ltd (JAC Motors).

Investasi besar besaran China adalah salah satu strategi ekonomi china dalam mengembangkan sayapnya untuk menjadi Negara adhikuasa yang baru menggantikan Amerika Serikat, diantarannya dengan memberi hutang kepada Negara-negara di dunia termasuk Indonesia, serta melakukan ekspansi bisnis besar-besaran seperti investasi manufaktur China. Pola yang diterapkan China sempat ditemukan oleh para Ekonom dimana China memberikan kemudahan hutang pada Negara Negara di dunia untuk membuat Negara Negara tersebut ketergantungan serta dapat memberikan pula kemudahan kemudahan kepada China untuk melakukan beberapa kegiatan yang salah satunya adalah Investasi.

Terlihat Indonesia memberikan beberapa insentif kemudahan bagi industry otomotif yang sudah lama dicanangkan bahkan sejak tahun 2010 tentunya saat ini juga menyambut baik pada investasi china dalam melakukan investasi atau ekspansi bisnisnya di Indonesia, terlihat dari artikel kebijakan industry otomotif yang diterbitkan oleh Kemenperin, Dirjen Industri Alat Transportasi dan Telematika Kementerian Perindustrian Budi Darmadi menegaskan, regulasi yang dibangun adalah agar semua Investor merasa nyaman berinvestasi di Indonesia. Ketika investasinya berkembang, multiplayer effect-nya akan sangat terasa bagi rakyat
Indonesia, yaitu dalam penyerapan tenaga kerja, tumbuhnya industri komponen dan jasa terkait. Berbagai insentif terus dilakukan demi bertumbuhnya industri otomotif nasional. Kita harus membantu mencari solusi ketika para investor mengalami masalah, demikian dikatakan Budi Darmadi. Kebijakan yang merugikan investor segera diselesaikan dengan instansi yang terkait dengan tujuan agar investasi terus bertumbuh. Sebuah komitmen yang hasilnya sudah terlihat di sektor otomotif. Optimisme pun terlihat jelas dari raut muka Budi Darmadi. Maklum, masa kejayaan industri otomotif nasional kembali bangkit. Menurutnya, target produksi mobil nasional tahun 2010 sebesar 650 ribu unit bakal tercapai. "Hingga Mei 2010 ini, sudah diproduksi 299 ribu unit mobil. Jika lima bulan pertama sudah hampir 300 ribu, saya kira target 650 ribu unit tahun ini cukup realistis," tandasnya. Fakta pun berbicara. Produsen mobil Toyota Avanza kini sudah bekerja lembur untuk memenuhi permintaan konsumen. Produsen truk Hino pun harus menambah jam kerja karena permintaan semakin meningkat. Jika sebelumnya hanya memproduksi 10 ribu unit saja, permintaan pasar yang tinggi menyebabkan produsen truk ini menambah produksinya menjadi 35 ribu unit. Membaiknya angka produksi industri mobil nasional tentu saja memberi efek yang luar biasa. Boleh jadi ini merupakan gambaran kondisi ekonomi nasional yang kian membaik. Apalagi jika bicara truk, yang notabene dipergunakan untuk kepentingan industri atau pengiriman barang. Jelas hal ini sesuatu yang sangat menggembirakan. Jika tahun 2008, total ekspor mobil mencapai 104.000 unit, dengan total produksi mencapai 600.884 unit. Angka ini menurun di tahun 2009, yang hanya memproduksi sebanyak 464.816 unit. Di 2010 ini, dengan melihat jumlah permintaan yang tinggi, angka 650.000 unit diyakini sebagai angka yang realistis tercapai. Sebuah mukjizat bagi industri mobil nasional, begitu kata Budi 
Darmadi. Tentu saja, meningkatnya kembali permintaan mobil di Indonesia akan memberikan berkah tersendiri bagi industri komponen dan sparepart juga jasajasa yang berkembang. Jika saat ini ada sekitar 400.000 orang tenaga kerja yang diserap, angka ini belum memperhitungkan tenaga kerja di perbengkelan dan tambal ban yang dikelola perorangan. Saat ini, ada 800 lebih industri komponen yang harus ditingkatkan jumlahnya menjadi lebih dari 1000 industri. Ini pertanda ekonomi nasional membaik. Belum lagi jika bicara industri sepeda motor nasional. Indonesia adalah produsen bebek terbesar di dunia. Lebih membanggakan lagi, untuk merk Yamaha dan Honda, 95 persen komponennya adalah dari komponen lokal. Saat ini, setidaknya ada 50 merk sepeda motor. Dimana 30 merknya adalah lokal dan dikembangkan di berbagai provinsi.

Sebelumnya pemerintahan Presiden Jokowi juga menggadang gadang mobil nasional yang diklaim dibuat oleh tangan tangan anak negeri, yang diberi nama Esemka, yang dibangun berdasarkan karya anak anak SMK di solo yang berhasi menciptakan sebuah mobil, presiden begitu tertarik sehingga menjadikan hal ini sebuah program dalam menghidupkan kembali industry otomotif nasional dalam negeri Indonesia, Pada tahun 2019 pabrik Esemka pertama yang dinaungi oleh PT. Solo Manufaktur Kreasi, melucurkan produk terbarunya berupa 40 mobil yang diklaim sebagai produk yang akan diproduksi masal oleh PT. Solo Manufaktur Kreasi, tetapi setelah terjadi beberapa penyelidikan oleh masyarakat bentuk, rupa dan mesin mobil tersebut hampir sama atau persis dengan sebuah produk mobil buatan manufaktur China, bahkan pemerintah diduga hanya mengimpor mobil tersebut dan melakukan rebadge terhadap mobil tersebut, tetapi PT SMK menolak pernyataan tersebut walaupun mereka mengakui ada beberapa part dari mobil tersebut yang diimpor langsung dari China.
Setelah isu mobil nasional Esemka yang diduga adalah sebuah produk Rebadge dari China, eksistensi Esemka tidak terlalu terdengar lagi, industry otomotif dalam 3 tahun terakhir dihebohkan dengan 2 merk kendaraan China yang merambah industry otomotif di Indonesia dengan menawarkan produk mobil yang diklaim memiliki fitur premium tetapi dengan harga yang terjangkau oleh daya beli masyrakat Indonesia, diantara merk mobil China yang masuk ke wilayah Indonesia adalah Wuling yang dibawa oleh PT.SGMW Motors Indonesia, DFSK yang dibawa oleh PT Sokonindo Automobile dan Morris Garage yang dibawa oleh SIAC Motor Corporation.

Memang diakui bahwa produk produk otomotif China menawarkan tawaran yang menarik bagi konsumen dengan menggunakan iklan yang massif serta menarik yang menawarkan produk dengan fitur yang premium melebihi rival rival sekelasnya tetapi dengan harga yang jauh lebih terjangkau dari pada mobil pabrikan Jepang ataupun Eropa yang sudah lebih dulu melakukan bisnis industry otomotif di Indonesia. Baru baru ini pada tahun 2020 dunia hukum dan otomotif Indonesia cukup dikagetkan dengan adanya Gugatan Konsumen yang diajukan oleh 7 orang Konsumen pengguna kendaraan DFSK 580 Turbo CVT ke Pengadilan, menurut keterangan para konsumen yang menuntut adanya cacat produk yang mereka alami terhadap produk DFSK tersebut berupa mobil tersebut diklaim tidak bisa dikemudikan untuk mendaki, mereka menilai hal ini adalah hal sangat krusial serta dapat membahayakan mereka serta konsumen-konsumen lainnya yang membeli mobil DFSK, Sokonindo Automobile DFSK Indonesia merespons keluhan sejumlah konsumennya terkait Glory 580 yang disebut tak kuat menanjak. Sebanyak tujuh konsumen diketahui telah melakukan gugatan hukum terhadap DFSK Indonesia ke Pengadilan Negeri Jakarta Selatan pada 3 Desember. Deputy 
Marketing Director DFSK Indonesia Major Qin mengatakan perusahaan sedang berkomunikasi dengan para konsumen tersebut untuk merespons masalah ini. Meski begitu Major tak memberi komentar saat ditanya mengenai upaya hukum sejumlah konsumen kepada perusahaan atas masalah produknya. Berdasarkan keterangan resmi dari pengacara ketujuh konsumen yang mengeluh, David Tobing, diketahui para konsumen tersebut merupakan pemilik Glory 580 turbo CVT produksi 2018. Para konsumen itu mengajukan gugatan perbuatan melawan hukum terhadap DFSK Indonesia selaku ATPM dan produsen serta enam pihak lain selaku dealer dan bengkel resmi DFSK.

Gugatan ini telah terdaftar online di Pengadilan Negeri Jakarta Selatan dengan Nomor register: PN JKT.SEL-122020BS2. Menurut David konsumen telah melaporkan serta melakukan perbaikan di bengkel resmi DFSK. Namun sampai saat ini mobil para konsumen masih mengalami kendala yang sama yaitu tidak dapat berjalan di tanjakan atau berada di kemacetan menanjak dengan posisi stop and go. "Klien kami mengalami gagal tanjak rata-rata lebih dari 2 kali. Hal ini membuat klien kami menjadi takut menggunakan kendaraan untuk berpergian atau pada saat berada di jalanan yang menanjak," ungkap David. Menurut David hal itu sangat berbahaya buat konsumen karena dapat mengakibatkan kecelakaan fatal dan membahayakan pihak lain. Menurut dia juga mobil tersebut mengandung cacat tersembunyi David bilang DFSK telah melanggar Kitab Undang-Undang Hukum Perdata, UndangUndang Perlindungan Konsumen dan Peraturan Menteri Perhubunggan Republik Indonesia Nomor PM 33 Tahun 2018, Tentang Pengujian Tipe Kendaraan Bermotor Pasal 18 point $\mathrm{b}$ dan $\mathrm{c}$ mengenai uji untuk kerja mesin serta uji kemampuan jalan. "Dimana DFSK dilarang memperdagangkan barang yang mengandung cacat tersembunyi dan wajib bertanggung jawab atas kerugian Para
Konsumen," kata David Dalam petitumnya para konsumen meminta agar Majelis Hakim menghukum DFSK untuk bertanggung jawab memberikan ganti rugi material sebesar Rp1,959 miliar yang merupakan total harga pembelian kendaraan para konsumen tersebut. Kemudian penggantian sebesar Rp1 miliar kepada masing-masing konsumen sehingga apabila ditotal kerugian immateril menjadi Rp7 miliar Karena para konsumen telah mengalami perasaan khawatir, takut selama menggunakan kendaraan dan juga habisnya waktu, pikiran dan tenaga selama mengalami kendala pada kendaraannya

Pada aturan hukum tentang Perlindungan Konsumen khususnya UU nomor 8 tahun 1999 tentang perlindungan konsumen dapat kita lihat bahwa dari awal konsideran Undang-Undang ini telah tertuang tentang bagaimana Indonesia membuat suatu undang undang yang telah mengakomodir pertumbuhan ekonomi dengan adanya perkembangan teknologi tanpa mengurangi kenyamanan dan keselamatan masyakarat sebagai konsumen dimana tercantum dalam konsideran poin kedua dan ketiga yang berbunyi "bahwa pembangunan perekonomian nasional pada era globalisasi harus dapat mendukung tumbuhnya dunia usaha sehingga mampu menghasilkan beraneka barang dan/atau jasa yang memiliki kandungan teknologi yang dapat meningkatkan kesejahteraan masyarakat banyak dan sekaligus mendapatkan kepastian atas barang dan/atau jasa yang diperoleh dari perdagangan tanpa mengakibatkan kerugian konsumen". "Bahwa semakin terbukanya pasar nasional sebagai akibat dari proses globalisasi ekonomi harus tetap menjamin peningkatan kesejahteraan masyarakat serta kepastian atas mutu, jumlah, dan keamanan barang dan/atau jasa yang diperolehnya di pasar." Maka dalam hal ini setiap pelaku usaha yang akan berbisnis di Indonesia baik menyediakan barang/jasa maka harus 
menjaga mutu dari barang/jasa yang ditawarkannya untuk melindungi konsumen yang memanfaatkan barang/jasa tersebut.

Pada pasal 2 UU Perlindungan Konsumen juga menyebutkan tentang asas-asas dari perlindungan konsumen tersebut dimana pasal 2 ini berbunyi "Perlindungan konsumen berasaskan manfaat, keadilan, keseimbangan, keamanan dan keselamatan konsumen, serta kepastian hukum." Dalam poin ini penulis ingin mengkaji secara lebih fokus pada kasus cacat produk diatas dengan asas keamanan dan keselamatan konsumen yang terdapat dalam UndangUndang dengan mengkaji secara lebih dalam makna dan penerapan asas ini terhadap terjadinya kasus diatas. Dan menyusun sebuah tulisan dalam bentuk makalah yang diberi judul "

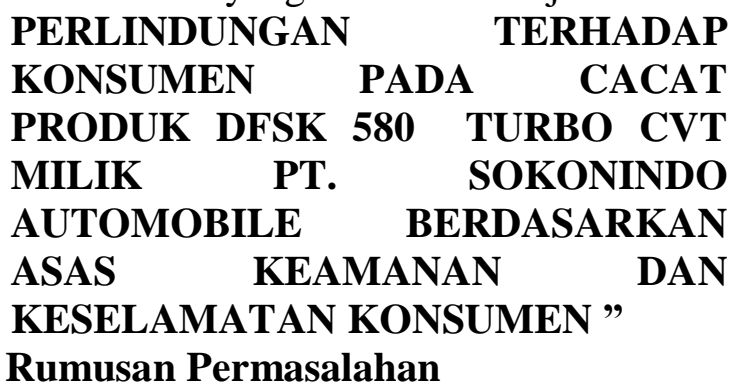

Untuk penulisan dan pembahasan yang lebih jelas dan terukur maka bedasarkan latar belakang yang telah diterangkan dan dipaparkan diatas selanjutnya penulis merumuskan permasalahan yang akan dibahas sebagai berikut:

1. Bagaimana bentuk Quality Control (Pengawasan Mutu) yang ditetapkan dalam peraturan perundang-undangan dalam sebuah produk kendaraan untuk menjamin keamanan dan keselamatan konsumen dalam kasus cacat produk DFSK 580 Turbo CVT milik PT. Sokonindo Automobile?

\section{METODE PENELITIAN}

Dalam penelitian ini jenis penelitian yang digunakan adalah penelitian hukum normatif. Dimana penelitian ini juga disebut sebagai penelitian doctrinal, dalam penelitian ini acap kali hukum dikonsepkan sebagai apa yang tertulis dalam peraturan perundang-undangan ( Law In Book) atau hukum dikonsepkan sebagai kaidah atau norma yang digunakan sebagai patokan bagi prilaku manusia

\section{PEMBAHASAN}

1. Bentuk Quality Control (Pengawasan Mutu) yang ditetapkan dalam peraturan perundang-undangan dalam sebuah produk kendaraan untuk menjamin keamanan dan keselamatan konsumen dalam kasus cacat produk DFSK 580 Turbo CVT milik PT. Sokonindo Automobile.

Masalah perlindungan konsumen adalah sebuah permasalahan yang tidak dapat terelakkan dan akan selalu menjadi bahan perbincangan di masyarakat, selama masih banyak konsumen yang dirugikan, masalahnya tidak akan pernah tuntas. Oleh karena itu, masalah perlindungan konsumen perlu di perhatikan. Permasalahan yang dihadapi konsumen Indonesia saat ini, seperti juga yang dialami konsumen di negara-negara berkembang lainnya, tidak hanya pada soal cara memilih barang, tetapi jauh lebih kompleks, yaitu mengenai kesadaran semua pihak, baik dari pengusaha, pemerintah, maupun konsumen sendiri tentang pentingnya perlindungan konsumen. Pelaku usaha seharusnya menyadari bahwa mereka harus menghargai hak-hak konsumen dengan memproduksi barang dan jasa berkualitas, aman dimakan/digunakan, mengikuti standar yang berlaku, serta harga yang sesuai. Dalam sebuah produk yang mengalami cacat produksi maka hal yang dapat dibahas dalam pertanggung jawabannya adalah mengenai tanggung jawab produk. Tanggung jawab produk yakni tanggung jawab hukum yang disebabkan oleh keadaan tertentu produk (cacat atau membahayakan orang lain). Tanggung jawab ini sifatnya mutlak 
(strict-liability) atau semua kerugian yang diderita seorang pemakai produk cacat atau membahayakan diri (diri sendiri dan orang lain) merupakan tanggung jawab mutlak dari pembuat produk atau mereka yang dipersamakan dengannya. Dengan diterapkannya tanggung jawab mutlak itu, pelaku usaha telah dianggap bersalah atas terjadinya kerugian pada konsumen akibat produk cacat yang bersangkutan (tanggung jawab tanpa kesalahan "liability without fault"), kecuali apabila ia dapat membuktikan sebaliknya bahwa kerugian itu bukan disebabkan produsen sehingga tidak dapat dipersalahkan padanya. Ada beberapa alasan mengapa prinsip tanggung jawab mutlak tersebut diterapkan dlaam tanggung jawab produk:

1. Di antara korban/konsumen disatu pihak dan produsen di lain pihak, beban kerugian seharusnya ditanggung oleh pihak yang memproduksi/mengeluarkan barangbarang cacat/berbahaya tersebut di pasaran.

2. Dengan menempatkan/mengedarkan barang-barang di pasaran berarti produsen menjamin bahwa barangbarang tersebut aman dan pantas untuk digunakan dan bilamana terbukti tidak demikian maka dia harus bertanggung jawab.

Sebenarnya tanpa menerapkan prinsip tanggung jawab mutlak pun produsen yang melakukan kesalahan tersebut dapat dituntut melalui proses penuntutan beruntun yaitu konsumen kepada pedagang ecera, pengecer kepada grosir, grosir kepapda distributor, distributor kepada agen dan agen kepada produsen. Penerapan prinsip strict liability ini dimaksudkan untuk menghilangkan proses yang panjang ini. Berkenaan dengan tanggung jawab produk, seorang pelaku usaha harus bertanggung. atas kerugian bagi konsumen baik kerugian fisik, kematian atau harta benda karena produk yang cacat. Pengertian produk yang cacat adalah setiap produk yang tidak dapat memenuhi tujuan pembuatannya baik karena kesengajaan atau kealpaan dalam proses produksinya maupun disebabkan hal-hal lain yang terjadi dalam peredarannya, atau tidak menyediakan syarat-syarat keamanan bagi manusia atau harta benda dalam penggunaannya, sebagaimana diharapkan. Untuk mengetahui kapan suatu prosuk mengalami cacat, dapat dibedakan atas tiga kemungkinan yaitu:

1. Kesalahan produksi

2. Cacat desain

3. Informasi yang tidak memadai

Tentunya dalam hal ini setiap produk yang akan dijual atau dipasarkan harus adanya Quality Control (Pengawasan Mutu) terhadap setiap produk yang akan dijual tersebut didalam kasus cacat produksi DFSK 580 CVT Turbo tampak tidak sempurna atau tidak dilakukannya pengawasan mutu dengan benar oleh pihak ATPM yang memasarkan produk tersebut, disebabkan setelah adanya beberapa keluhan dari beberapa konsumen tetap ATPM yaitu PT. Sokonindo Automobile tidak dapat menyelesaikan masalah tersebut yang dimana pihak ATPM justru berlepas diri bahwa produk mereka sudah sesuai dengan standard, untuk itu dalam aturan perundang undangan tentunya telah ada ukuran atau metode tertentu yang harus dijalankan oleh pihak ATPM sebelum memasarkan produknya. Salah satunya dalam hal ini telah diatur dalam Peraturan Menteri Perhubungan Nomor 33 Tahun 2018 Tentang Pengujian Tipe Kendaraan Bermotor, Dalam hal ini Indonesia menerapkan aturan yang cukup ketat dalam menguji kelayakan sebuah kendaraan bermotor yang akan beroperasi atau dipasarkan di Indonesia dalam hal ini sudah dijelaskan kriteria pengujian secara rinci yang harus dilakukan oleh ATPM pada pasal 18 dan 19 yang berbunyi:

Pasal 18 Pengujian laik jalan terhadap Kendaraan Bermotor dalam bentuk landasan sebagaimana dimaksud dalam Pasal 9 paling sedikit meliputi:

a) Uji emisi gas buang;

b) Uji kebisingan suara; 
c) Uji efisiensi rem utama dan rem parkir;

d) Uji kincup roda depan;

e) Uji tingkat suara klakson;

f) Uji daya pancar dan arah sinar lampu utama;

g) Uji radius putar;

h) Uji akurasi alat penunjuk kecepatan;

i) uji kesesuaian kinerja roda dan kondisi ban;

j) Uji kesesuaian daya mesin penggerak terhadap berat kendaraan bermotor; dan

k) Uji berat kendaraan Bermotor.

Pasal 19 Pengujian laik jalan terhadap

Kendaraan Bermotor dalam Keadaan Lengkap selain melakukan pengujian sebagaimana dimaksud dalam Pasal 18 dilakukan pengujian terhadap:
a. uji posisi roda depan;
b. uji unjuk kerja mesin;
c. uji kemampuan jalan;
d. uji penghapus kaca depan;
e. uji sabuk keselamatan; dan
f. uji suspensi.

Dari hal hal tersebut diatas kita dapat menyimpulkan bahwa sebenarnya Indonesia secara aturan memiliki aturan yang jelas dan ketat dalam memberikan ukuran kelayakan dan kelaikan jalan bagi sebuah produk kendaraan bermotor, dari dua poin pasal tersebut jika meneliti kasus yang bersangkutan bahwa PT. Sokonindo Automobile tidak melakukan pengujian yang layak yang terutama bertentangan dengan pasal 19 huruf $b$ tentang uji unjuk kerja mesin serta uji kelayakan jalan, dimana seharusnya PT. Sokonindo Automobile harus lebih memperhatikan kualitas dari setiap produknya yang harus disesuaikan dengan kondisi geografis dan keadaan iklim Indonesia agar setiap konsumen yang membeli produk tersebut tidak dirugikan atau membahayakan konsumen yang menggunakan produk tersebut.

Selain dalam Permen Nomor 33 Tahun 2018 yang mengatur perlindungan konsumen terhadap kelayakan sebuah kendaraan bermotor, dalam kasus ini juga berkaitan dengan apa yang diatur dalam
UU Nomor 8 Tahun 1999 tentang Perlindungan Konsumen sebagai aturan yang utama dan berlaku umum, didalam UU ini telah diterangkan bagaimana sebuah produk yang akan dipasarkan atau jasa haruslah menjamin keamanan dan keselamatan pemakainya, hal ini dituangkan dalam asas keamanan dan keselamatan konsumen, Asas keamanan dan keselamatan konsumen dimaksudkan untuk memberikan jaminan atas keamanan dan keselamatan kepada konsumen dalam penggunaan, pemakaian, dan pemanfaatan barang dan/atau jasa yang dikonsumsi atau digunakan

Secara umum dikenal ada 4 (empat) hak dasar kosumen, yaitu:

1. Hak untuk mendapatkan keamanan (the right to safety) Hak atas keamanan ini dimaksudkan untuk menjamin keamanan konsumen dalam penggunaan barang atau jasa yang diperolehnya, sehingga konsumen dapat terhindar dari kerugian apabila mengonsumsi suatu produk.

2. Hak untuk mendapatkan informasi (the right to be informed) Hak atas informasi ini sangat penting, karena tidak memadainya informasi yang disampaikan kepada konsumen ini dapat juga merupakan salah satu bentuk cacat produk, yaitu yang dikenal dengan cacat instruksi atau cacat karena informasi yang tidak memadai. Hak atas informasi yang jelas dan benar dimaksudkan agar konsumen dapat memperoleh gambaran yang benar tentang suatu produk, karena dengan informasi tersebut, konsumen dapat memilih produk yang diinginkan/sesuai kebutuhannya serta terhindar dari kerugian akibat kesalahan dalam penggunaan produk.

3. Hak untuk memilih (the right to choose) Hak untuk memilih dimaksudkan untuk memberikan kebebasan kepada konsumen untuk memilih produk-produk tertentu sesuai 
dengan kebutuhannya, tanpa ada tekanan dari pihak luar.

4. Hak untuk didengar (the right to be heard) Hak untuk didengar ini merupakan hak dari konsumen agar tidak dirugikan lebih lanjut, atau hak untuk menghindarkan diri dari kerugian. Hak ini dapat berupa pertanyaan tentang berbagai hal yang berkaitan dengan produk-produk tertentu apabila informasi yang diperoleh tentang produk tersebut kurang memadai, ataukah berupa pengaduan atas adanya kerugian yang telah dialami akibat penggunaan suatu produk, atau yang berupa pernyataan/pendapat tentang suatu kebijakan pemerintah yang berkaitan dengan kepentingan konsumen.

Dari keempat tersebut diatas yang telah dituangkan dalam UU No 8 Tahun 1999 tentang perlindungan konsumen dapat dikhususkan bahwa hak yang paling bertepatan dengan kasus diatas adalah hak untuk mendapatkan keamanan dan hak untuk didengar, dimana hak konsumen untuk keamanan dapat menjamin para pengguna DFSK 580 CVT Turbo haruslah mendapatkan produk yang dijamin keamananya guna kenyamanan mereka sebagai konsumen, serta dalam hal ini hak untuk didengar adalah yang dapat digunakan oleh para konsumen untuk dituntut kepada pihak ATPM selaku pengusaha guna menjamin segala keamanan dan keselamatan konsumen atas produk yang mereka pasarkan.

Ironi yang terjadi pada industry otomotif Indonesia sejak bertahun tahun berdirinya industry otomotif yang lebih dulu diisi oleh pabrikan Jepang dan Eropa belum pernah ditemukan kejadian yang fatal seperti ketidaklayakan jalan yang dilakukan oleh pabrikan China tersebut, memang dalam beberapa waktu ada beberapa produk kendaraan Jepang dan Eropa yang diperintahkan untuk kembali ke Dealer untuk diganti beberapa part tertentu hasil penelitian ATPM atau yang biasa dikenal dengan Recall, Recall sendiri adalah sebuah metode yang diatur oleh undang undang yang dapat dilakukan oleh pihak ATPM atau Distributor Merk kendaraan untuk menarik kembali produknya guna perbaikan atau penggantian part yang dianggap bermasalah dan akan menimbulkan efek negative dikemudian hari, aturan penarikan kembali ini diatur dalam Peraturan Menteri Perhubungan Nomor 53 Tahun 2019 Tentang Tata Cara Penarikan Kembali Kendaraan Bermotor, hal ini telah diatur untuk dipatuhi oleh seluruh pabrik, distributor atau pemegang merk kendaraan bermotor adapun tata cara penarikan kembali atau Recall adalah sebagai berikut Pasal 7:

Perakit, pembuat, pengimpor, distributor, atau pemegang merek kendaraan bermotor harus memiliki standar operasional prosedur tertulis. Standar tersebut harus diumumkan kepada masyarakat.

Pasal 8:

(1) Setelah menyampaikan laporan, perakit, pembuat, pengimpor, distributor, atau pemegang merek kendaraan bermotor melakukan pemberitahuan kepada pemilik Kendaraan Bermotor untuk dilakukan penarikan kembali.

(2) Dalam hal keadaan mendesak, penarikan kembali kendaraan bermotor dapat dilakukan sebelum menyampaikan laporan kepada Menteri.

(3) Pemberitahuan kepada pemilik Kendaraan Bermotor sebagaimana dimaksud pada ayat (1) dapat disampaikan melalui: a. telepon; b. surat; c. media cetak; dan/atau d. media elektronik.

Pasal 9:

Kendaraan bermotor yang telah dilakukan penarikan kembali sebagaimana dimaksud dalam pasal 8 ayat (1) dilakukan pemeriksaan dan/atau perbaikan oleh perakit, pembuat, pengimpor, distributor, atau pemegang merek kendaraan bermotor. Perbaikan kendaraan bermotor dilakukan 
sesuai standar operasional prosedur dari perakit, pembuat, pengimpor, distributor, atau pemegang merek kendaraan bermotor. Kendaraan bermotor yang telah dilakukan pemeriksaan dan/atau perbaikan sebagaimana pada ayat (1) dilaporkan kepada Menteri Melalui Direktur Jenderal.

Bahkan dalam hal ini Negara sudah memberikan tata cara yang jelas mengenai apabila sebuah produk kendaraan bermotor mengalami cacat produksi yang ditemukan setelah kendaraan tersebut dipasarkan maka ATPM atau pengusaha diwajibkan untuk melakukan penarikan kembali (Recall) untuk melakukan perbaikan pada produk bersangkutan yang telah didistribusikan pada konsumen, sedangkan dalam kasus ini PT.Sokonindo Automobile selaku ATPM tidak melakukan penarikan kembali terhadap produknya dengan seri DFSK 580 Turbo CVT, tentu dalam hal ini PT.Sokonindo Automobile sudah melanggar 3 aturan sekaligus, pertama UU nomor 8 tahun 1999 tentang Perlindungan Konsumen, Kedua Peraturan Menteri Perhubungan Nomor 33 Tahun 2018 Tentang Pengujian Tipe Kendaraan Bermotor dan Peraturan Menteri Perhubungan Nomor 53 Tahun 2019 Tentang Tentang Tata Cara Penarikan Kembali Kendaraan Bermotor.

\section{KESIMPULAN}

Perlindungan konsumen adalah fokus isu yang sangat penting dalam proses usaha di Indonesia, dimana setiap barang/jasa yang ditawarkan oleh pengusaha kepada konsumen akhir haruslah terjaga dalam setiap mutu, keamanan, kenyamanan dan manfaat yang benar yang didapatkan oleh konsumen, pada pembahasan ini penulis bekesimpulan bahwa pada kasus DFSK 580 Turbo CVT banyak terjadi pelanggaran hukum yang dilakukan oleh PT. Sokonindo Automobile sebagai ATPM pemegang merk DFSK kendaraan Pabrikan China di Indonesia, dimana kemampuan mobil yang di klaim tidak bisa digunakan pada jalur pendakian atau menanjak itu dirasakan sangat fatal oleh konsumen, tentunya secara prosedur yang dilakukan oleh 7 orang tersebut sudah benar dengan melakukan gugatan pada pengadilan terkait kasus yang dilakukan oleh PT Sokonindo Automobile, dan aturan hukum di Indonesia tentang standard kelayakan dan segala metode yang melindungi konsumen kendaraan bermotor di Indonesia sebenarnya juga sudah sangat baik. Tetapi dalam hal ini penulis berpendapat bahwa adanya kelonggaran pemerintah selaku otoritas hukum tertinggi yang memberikan insentif kemudahan dalam berbisnis pada produk kendaraan bermotor China, adanya sebuah pembedaan perlakuan antara ATPM Jepang dan/atau Eropa dengan yang dilakukan pada ATPM China, penulis berpendapat bahwa hal ini tidak lepas dari keadaan Indonesia yang sedang dijerat dengan hutang luar negeri yang cukup banyak kepada Negara Tiongkok/ China, sehingga pihak China dapat sedikit banyaknya mengintervensi Indonesia untuk dapat memberikan kelonggaran dalam setiap stadarisasi produk yang diterapkan dalam wilayah Indonesia, menurut penulis bahwa apapun itu tekanan yang diciptakan dari Negara lain tidak seharusnya menjadi penyebab sebuah Negara untuk membahayakan masyarakat sebagai konsumen.

\section{SARAN}

Dalam kasus ini ataupun kasus yang akan terjadi di masa yang akan dating otoritas pengawas kendaraan bermotor yaitu Kementrian Perhubungan umumnya Pemerintah, harus menegakan aturan hukum dalam setiap stadarisasi produk kendaraan bermotor dengan sebenarbenarnya dan sebaik-baiknya, disebabkan apapun kesalahan ataupun kelonggaran dalam pengujian kelayakan kendaraan dapat membahayakan setiap masyarakat Indonesia sebagai konsumen, dan Pemerintah harus memberikan standard yang sama bagi setiap ATPM atau pemegang merk kendaraan bermotor dari semua Negara yang berinvestasi di 
Indonesia, agar masyarakat mendapatkan hak memilih yang benar yang diamanatkan oleh UU Nomor 8 Tahun 1999 tentang Perlindungan Konsumen serta hak untuk mendapatkan keamanan dan keselamatan dalam setiap penggunaan produk kendaraan bermotor di Indonesia.

\section{DAFTAR PUSTAKA}

AzAdriyanti Akbar, Penerapan Asas Keamanan Dan Keselamatan Konsumen Terhadap Obat Impor Yang Tidak Melalui Badan Pom, Skripsi FH Universitas Hasanudin 2010.

$\mathrm{Az}$ Nasution ,Hukum Perlindungan Konsumen Suatu Pengantar. Jakarta: Daya Widya 1999.

Celina Tri Siwi Kristiyanti, Hukum Perlindungan Konsumen, cetakan pertama, Jakarta: Sinar Grafika. 2018.

Dara Ayu Maharani, Bambang Eko Turisno, Suradi, Perlindungan Hukum Terhadap Layanan Purna Jual (After Sales Service) (Studi Pada Putusan Nomor: 336/Pdt.G/2013/Pn Jkt.Bar), Diponegoro Law Journal Volume 6, Nomor 1, Tahun 2017.

Edwin Makarim. Kompilasi Hukum Telematika. Jakarta: Raja Grafindo Persada 2003.

https://oto.detik.com/mobil/d4935440/mg-masuk-indonesiamobil-china-bisa-geser-dominasijepang Diakses tanggal 12 Desember 2020

https://otomotif.kompas.com/read/2019/08 /14/063200015/benarkah-esemkarebadge-dari-mobil-china Diakses tanggal 12 Desember 2020

https://www.cnbcindonesia.com/news/201 91112120446-4-114575/utangchina-mencengkeram-duniatermasuk-indonesia Diakses tanggal 11 Desember 2020

https://www.cnbcindonesia.com/news/202 00129141359-4-133660/saatchina-makin-ekspansif-ke- indonesia-baik-atau-buruk, diakses tanggal 11 desember 2020

https://www.cnnindonesia.com/teknologi/2 0191018155212-384-

440718/janji-surga-investasirp100-t-buat-otomotif-indonesia Diakses tanggal 11 Desember 2020

https://www.cnnindonesia.com/teknologi/2 0201204105010-384577893/dfsk-indonesia-responsgugatan-glory-580-loyo-ditanjakan Diakses tanggal 12 Desember 2020

Kina Karya Indonesia, Kemana Arah Kebijakan Industry Otomotif Indonesia, edisi 1, Kemenperin, Jakarta, 2010.

Miru, Ahmadi, \& Yodo, Sutarman . Hukum Perlindungan Konsumen. Jakarta: Rajawali Pers. 2010.

Peraturan Menteri Perhubungan Nomor 33 Tahun 2018 Tentang Pengujian Tipe Kendaraan Bermotor.

Peraturan Menteri Perhubungan Nomor 53 Tahun 2019 Tentang Tata Cara Penarikan Kembali Kendaraan Bermotor.

Undang-Undang Negara Republik Indonesia Nomor 8 Tahun 1999 Tentang Perlindungan Konsumen, Lembaran Negara Republik Indonesia Tahun 1999 Nomor 42.

Yusuf Shofie, Kapita Selekta Hukum Perlindungan Konsumen di Indonesia, cetakan pertama, Bandung: PT. Citra Aditya Bakti, 2008. 